\title{
Glutathione S-transferase genotypes modify lung function decline in the general population: SAPALDIA cohort study
} Medea Imboden 1,3, Sara H Downs², Oliver Senn1, Gabor Matyas'3, Otto Brändli ${ }^{4}$, Erich W Russi ${ }^{5}$, Christian Schindler ${ }^{2}$, Ursula AckermannLiebrich $^{2}$, Wolfgang Berger ${ }^{3}$, Nicole M Probst-Hensch ${ }^{* 1}$ and the SAPALDIA Team $1,2,6$

\author{
Address: ${ }^{1}$ Institutes of Social and Preventive Medicine \& Surgical Pathology, Molecular Epidemiology/Cancer Registry, University of Zurich \& \\ University Hospital Zurich, Switzerland, ${ }^{2}$ Institute of Social and Preventive Medicine, University of Basel, Switzerland, ${ }^{3}$ Institute of Medical \\ Genetics, Division of Medical Molecular Genetics and Gene Diagnostics, University of Zurich, Switzerland, ${ }^{2}$ Zürcher Höhenklinik, Wald, \\ Switzerland, ${ }^{5}$ Department of Pneumology, University Hospital Zurich, Switzerland and ${ }^{6}$ Division of Pulmonary Medicine, University Hospitals of \\ Geneva, Switzerland \\ Email: Medea Imboden - imboden@medgen.unizh.ch; Sara H Downs - s.downs@unibas.ch; Oliver Senn - oliver.senn@usz.ch; \\ Gabor Matyas - matyas@medgen.unizh.ch; Otto Brändli - otto.braendli@zhw.ch; Erich W Russi - erich.russi@usz.ch; \\ Christian Schindler - christian.schindler@unibas.ch; Ursula Ackermann-Liebrich - ursula.ackermann-liebrich@unibas.ch; \\ Wolfgang Berger - berger@medgen.unizh.ch; Nicole M Probst-Hensch* - Nicole.Probst@usz.ch; the SAPALDIA Team - contact-corresponding- \\ author@for-study-group-information.com \\ * Corresponding author
}

Published: II January 2007

Respiratory Research 2007, 8:2 doi:10.1186/1465-992I-8-2
Received: 22 May 2006

Accepted: II January 2007

This article is available from: http://respiratory-research.com/content/8/I/2

(C) 2007 Imboden et al; licensee BioMed Central Ltd.

This is an Open Access article distributed under the terms of the Creative Commons Attribution License (http://creativecommons.org/licenses/by/2.0), which permits unrestricted use, distribution, and reproduction in any medium, provided the original work is properly cited.

\begin{abstract}
Background: Understanding the environmental and genetic risk factors of accelerated lung function decline in the general population is a first step in a prevention strategy against the worldwide increasing respiratory pathology of chronic obstructive pulmonary disease (COPD). Deficiency in antioxidative and detoxifying Glutathione S-transferase (GST) gene has been associated with poorer lung function in children, smokers and patients with respiratory diseases. In the present study, we assessed whether low activity variants in GST genes are also associated with accelerated lung function decline in the general adult population.
\end{abstract}

Methods: We examined with multiple regression analysis the association of polymorphisms in GSTMI, GSTTI and GSTPI genes with annual decline in FEVI, FVC, and $\mathrm{FEF}_{25-75}$ during II years of follow-up in 4686 subjects of the prospective SAPALDIA cohort representative of the Swiss general population. Effect modification by smoking, gender, bronchial hyperresponisveness and age was studied.

Results: The associations of GST genotypes with FEVI, FVC, and $\mathrm{FEF}_{25-75}$ were comparable in direction, but most consistent for FEVI. GSTTI homozygous gene deletion alone or in combination with GSTMI homozygous gene deletion was associated with excess decline in FEVI in men, but not women, irrespective of smoking status. The additional mean annual decline in FEVI in men with GSTTI and concurrent GSTMI gene deletion was $-8.3 \mathrm{ml} / \mathrm{yr}$ ( $95 \%$ confidence interval: -12.6 to -3.9 ) relative to men without these gene deletions. The GSTTI effect on the FEVI decline comparable to the observed difference in FEVI decline between never and persistent smoking men. Effect modification by gender was statistically significant.

Conclusion: Our results suggest that genetic GSTTI deficiency is a prevalent and strong determinant of accelerated lung function decline in the male general population. 


\section{Background}

According to estimates by the World Health Organization chronic obstructive pulmonary disease (COPD) has become the fourth most common single cause of death and its prevalence is further increasing world wide [1]. COPD is characterized by irreversible and progressive bronchial obstruction and is associated with persistent airway inflammation [2]. Excess age-related lung function decline is considered a subclinical correlate of COPD and is associated with morbidity and premature mortality [3]. The identification of risk factors leading to accelerated lung function decline is thus needed for efficient COPD prevention. Modifiable risk factors for COPD include active cigarette smoking, occupational dust and fume exposure [4] and possibly air pollution [5] and passive smoking [6].

But there is also broad evidence that genetic differences influence the individual's susceptibility to COPD. Rare mutations in the SERPINA1 gene [7], leading to severe alpha 1-antitrypsin deficiency, in the SERPINE2, protease inhibitor 7 gene, and in the ELN, elastin gene, have been identified as genetic predisposing factor in families with early onset COPD $[8,9]$. To what degree common genetic variants influence susceptibility to COPD in the general population is the focus of intensive research efforts. There is limited evidence from association studies on common genetic polymorphisms in various candidate genes that modify the individual's risk for lung function deficits and COPD [10-13]. But several lines of evidence point to the involvement of the supergene family of glutathione Stransferase (GST) in respiratory disease etiology, including that of COPD. Given their function in the metabolism of environmental toxicants as well as in the inactivation of reactive oxygen species, these genes represent promising candidates for modification of the susceptibility to tobacco-smoke derived and other inhaled irritants $[14,15]$. Two prevalent homozygous gene deletions of the Mu-1 and Theta-1 GST members (GSTM1 and GSTT1) have repeatedly been associated with increased susceptibility to respiratory disease and lung function deficits in children, asthmatics, and smokers with respiratory symptoms [16-20]. It is, however, unknown whether these GST polymorphisms also influence lung function in the general population. We therefore investigated the association of the three most studied GST polymorphisms (GSTM1 and GSTT1 gene deletions and GSTP1 Ile105Val single nucleotide polymorphism) with change in lung function over an eleven year follow-up using the population-based SAPALDIA cohort (Swiss Cohort Study on Air Pollutants and Lung and Heart Diseases in Adults) and hypothesized that low-activity variants would also accelerate lung function decline in the general adult population.

\section{Methods \\ Study population}

The SAPALDIA cohort study has been described in details elsewhere $[21,22]$. In brief, participants predominantly of European-Caucasian ethnicity and Swiss nationality, were randomly selected from eight regional population registries [21,22]. Health examinations at baseline (1991) and follow-up (2002) included an interview about respiratory health, occupational and lifestyle exposures as well as spirometry, a methacholine bronchial challenge test and end-expiratory carbon monoxide measurement. Participants gave informed consent at both surveys separately for health examination, interview and blood analysis. The SAPALDIA cohort study complies with the Helsinki Declaration and has received ethical approval by the central ethics committee of the Swiss Academy of Medical Sciences and the Cantonal Ethics Committees for each of the eight examination areas.

Participation rate in SAPALDIA at baseline was 59.3\%. Of 9651 participants examined at baseline, 8047 subjects (86\%) agreed to participate fully or partially at follow-up. For the present investigation no selection of SAPALDIA participants was made, but we included all subjects with complete information on outcome and covariate data. 5973 subjects (62\%) completed the entire follow-up protocol including spirometry and blood sampling. For 275 participants no DNA was available for genetic testing due to refusal or insufficient blood sample volume. Valid spirometry data on FEV1, FVC and $\mathrm{FEF}_{25}{ }^{-} 75$ were not available from both surveys for 215, 310 and 373 participants, respectively. Genotyping for one or more genetic polymorphisms failed in 13 participants. Missing information on one or more covariates included in the regression models further diminished the sample size $(\mathrm{n}=784)$. The final sample size was 4686, 4591 and 4528 subjects for the investigation of annual change in FEV1, FVC and $\mathrm{FEF}_{25^{-} 75}$, respectively. Comparison of the baseline characteristics of SAPALDIA cohort participants included in and excluded from this analysis revealed that excluded SAPALDIA participants were on average older, more likely to have been smokers at baseline examination, and had reported a slightly higher number of pack-years at baseline (Table 1). Accordingly lung function was slightly lower and the proportion of subjects with an FEV1/FVC ratio below $70 \%$ was slightly higher in non-participants excluded from this current investigation.

\section{INSERT [Table 1]}

\section{Spirometry and bronchial hyperresponsiveness}

The spirometry measurement procedures at both time points have been described elsewhere in detail $[21,22]$. Briefly, identical spirometer devices (Sensormedics model 2200, Yorba Linda, USA) and protocols were used at base- 
Table I: Baseline characteristics* of the included versus excluded SAPALDIA participants

\begin{tabular}{lcc}
\hline Variables: & Participants Included $\mathrm{n}=4686$ & Participants Excluded $+\mathrm{n}=4965$ \\
\hline Women [N/\%] & $2455 / 52.4$ & $2453 / 49.4$ \\
Age [years] & $40.8( \pm 11.5)$ & $41.3( \pm 11.8)$ \\
BMI at baseline [kg/m2] & $23.7( \pm 3.6)$ & $24.2( \pm 4.1)$ \\
& & \\
Smoking & $2325 / 49.6$ & $1904 / 38.5$ \\
Non-smokers [N/\%] & $948 / 20.2$ & $1227 / 24.8$ \\
Former smokers [N/\%] & $1413 / 30.2$ & $1819 / 36.7$ \\
Current smokers [N/\%] & & $19.6( \pm 20.1)$ \\
& $18.4( \pm 18.4)$ & \\
Pack-years at baseline $¥$ & & $3.5( \pm 0.9)$ \\
Lung Function & $3.6( \pm 0.8)$ & $98.0( \pm 14.8)$ \\
FEVI [L] & $100.2( \pm 13.3)$ & $78.9( \pm 8.4)$ \\
FEVI \% pred. $\$$ & $79.2( \pm 7.6)$ & $510 / 12.0$ \\
FEVI/FVC & $468 / 10.1$ & \\
FEVI/FVC $<70 \%$ & & \\
\hline
\end{tabular}

* expressed as mean $( \pm S D)$ for quantitative variables and absolute numbers/percentages for categorical variable.

† SAPALDIA participants at the baseline examination who did not participate at follow-up $(n=3678)$ [2I] or who were excluded from the present analysis due to missing information on outcome or covariate data $(n=1287)$.

$\ddagger$ mean of pack-years among ever smoking subjects. Participants were defined as ever-smokers if they had smoked at least 20 packs of cigarettes or $360 \mathrm{~g}$ of tobacco in their life.

$\S$ FEVI \% predicted calculations based on SAPALDIA specific prediction equations $[55,56]$.

line and follow-up and their comparability was assessed prior to the follow-up study [23]. Three to maximal eight forced expiratory lung function manoeuvres were performed by each participant and a minimum of two acceptable forced expiratory flows, forced vital capacity (FVC), forced expiratory volume in the first second $\left(\mathrm{FEV}_{1}\right)$ and forced expiratory flows during the middle half of the FVC $\left(\mathrm{FEF}_{25-75}\right)$ complying with American Thoracic Society criteria [24] were obtained. Expiratory flow measures with the highest sum of $\mathrm{FVC}, \mathrm{FEV}_{1}$ and $\mathrm{FEF}_{25-75}$ were taken from the same flow-volume curves.

Bronchial hyperresponsiveness (BHR) to methacholine chloride (Provocholine ${ }^{\varpi}$, Roche, Nutley, New Jersey, USA) was defined as presence of a $20 \%$ or greater drop in FEV1 compared to the highest FEV1-value measured during the test. Increasing concentrations of methacholine (0.39, $1.56,6.25$, and $25.0 \mathrm{mg} / \mathrm{ml}$ solutions in a phosphate buffer without phenol) were administered through an aerosol dosimeter (Mefar MB3, Bovezzo, Italy) up to a cumulative dose of $2 \mathrm{mg}(8.37 \mathrm{ug} / \mathrm{mol})$.

\section{Genotyping}

DNA was extracted from EDTA blood using the PUREGENE $^{\mathrm{TM}}$ DNA purification kit (GENTRA Systems, Minneapolis, USA)[21]. In all subjects GSTM1 and GSTT1 gene deletions and a single nucleotide polymorphism (SNP) in GSTP1 leading to the amino acid substitution Ile105Val were genotyped on the ABI Prism 7000 sequence detection system (Applied Biosystems, Rotkreuz, Switzerland) using 5 'nuclease real time PCR (TaqMan ${ }^{\circledR}$ ) assay and fluo- rescently labeled allele-specific probes. Following primers and probes were used for GSTM1: forward 5'-GGACATTTTGGAGAACCAGACC-3' and reverse 5'-CTGGATTGTAGCAGATCATGCC-3' primers and GSTM1-specific probe 5'-VIC-TGGACAACCATATGCAG-MGB-3'; for GSTT1: forward 5'-GTCATTCTGAAGGCCAAGGACTT-3' and reverse 5'-GGCATCAGCTTCTGCTTTATGGT-3' primers and GSTT1-specific probe 5'-FAM-CACCTGCAGACCCC-MGB-3'; for GSTP1 Ile105Val: forward 5'CCTGGTGGACATGGTGAATGAC-3' and reverse 5'CAGATGCTCACATAGTTGGTGTAGA-3' primers and Ile105 -specific probe 5'-VIC-CTGCAAATACATCTCCMGB-3'and Val 105 -specific probe 5'-FAMCTGCAAATACGTCTCC-MGB-3'. GSTM1/GSTT1 assays were repeated for all DNA samples carrying double homozygous GSTM1 and GSTT1 deletions using internal positive GSTP1 controls. All double homozygous deletion carriers could be confirmed. With this approach, hemizygous GSTM1 or GSTT1 carriers were not distinguishable from homozygous carriers. In addition a 5\% random sample of all DNA samples was regenotyped with highest reproducibility (>99.5\%). Hardy-Weinberg equilibrium (HWE) was tested for GSTP1 Ile105Val using Arlequin (Version 2.000) software [25].

\section{Statistical analysis}

The dependent variable, annual change in lung function, was calculated by dividing the difference between followup and baseline lung function by the number of followup years. Multiple linear regression analysis was used to estimate in a fixed effect model of the association of GST 
genotypes with annual change in lung function. Covariates included in the models were baseline lung function, age, sex, height, weight change during follow-up, study center, level of education, exposure to gas and dust at work at baseline, smoking status at baseline and at followup, pack-years smoked at baseline and during follow-up. Cumulative cigarette smoking exposure was summarized in two separate variables: "pack-years smoked up to baseline" and "pack-years smoked during follow-up". The following categories of smoking status were derived for the current study: "Never smokers" reported to be non-smokers at both surveys $(\mathrm{n}=2258)$. "Ever smokers" had to have smoked more than 20 packs of cigarettes or more than $360 \mathrm{~g}$ of tobacco $(\mathrm{n}=2428)$ in their lifetime by the end of the follow-up period. Ever smokers were further divided into: "persistent smokers" reported current smoking at both surveys $(\mathrm{n}=1026)$, and "others" were all remaining subjects, comprising participants reporting at both surveys former smoking $(\mathrm{n}=944)$, quitting smoking during follow-up $(\mathrm{n}=387)$, starting smoking during follow-up $(\mathrm{n}=38)$, non-smoking at baseline and former smoking at follow-up $(\mathrm{n}=29)$ and former smoking at baseline and current smoking at follow-up $(\mathrm{n}=4) .48$ participants provided inconsistent smoking information. Exclusion of these subjects in a sensitivity analysis did not change the strength or the direction of the association observed. Effect modification of genotype/lung function associations by gender, smoking status, and smoking intensity (pack-years up to baseline and during follow-up in ever smokers), as well as BHR and age, was assessed by including according multiplicative interaction terms in the regression models. Trend tests for the combination of GSTT1 and GSTM1 genotypes were conducted by using a genotype combination variable coded as "presence of zero, one and two gene deletion polymorphisms" as ordinal variable in the model. Two-sided p-values of $<0.05$ and $<0.10$ were considered as statistically significant for main effects and interactions [26], respectively. Correction for multiple testing was done using the conservative Bonferroni correction. The associations were corrected for the number of statistical tests performed (main effects and interactions with gender and smoking intensity) (thirty comparisons per lung function parameter investigated, consisting of fifteen tests in men and fifteen tests in women: all; never smokers; persistent smokers). The Bonferroni corrected significance level for the $a$ priori hypotheses regarding association between GST genotypes and lung function change in men and women including the $a$ priori assessment of interaction with gender and smoking and was $P>0.0017$. Sensitivity analyses regarding age and BHR were not corrected for multiple testing. All analyses were conducted using STATA SE version 8.0 (Stata Corporation, TX, USA).

\section{Results}

Characteristics of the study population are summarized in Table 2. The study included more women (52.4\%) than men $(47.6 \%)$. Reflecting recruitment as a random sample of the Swiss general population participants had on average good lung function at baseline and follow-up. FEV1 percent predicted at baseline and follow-up was $100.2 \%$ and $97.0 \%$ of predicted values, respectively. The mean annual change in FEV1 was $-39.6 \mathrm{ml} / \mathrm{yr}(\mathrm{SD}: \pm 33.6)$ in men and $-31.8 \mathrm{ml} / \mathrm{yr}( \pm 26.2)$ in women, respectively. Women were more likely to be never smokers. Among smoking subjects, men smoked on average more heavily than women (21.8 pack-years vs. 14.5 pack-years at baseline; 7.1 vs. 5.5 pack-years during follow-up). The observed GST genotype distributions agreed well with previous reports in Caucasians $[19,27,28]$. GSTM1 and GSTT1 null genotypes were present in 53\% and $18 \%$ of all subjects. The homozygous GSTP1 Val/Val genotype was present in $9.4 \%$ and its allele distribution was in HardyWeinberg equilibrium.

\section{INSERT [Table 2]}

\section{Association of GST genotypes with lung function decline}

No independent association of GSTM1 or GSTP1 genotype with any of the lung function parameters was observed, irrespective of gender. GSTT1 gene deletion alone or in combination with GSTM1 deletion was associated with accelerated lung function decline in men, but not women. Men homozygous for the GSTT1 gene deletion exhibited an excess annual change in FEV1 of $-5.3 \mathrm{ml} /$ yr $(\mathrm{P}=0.001)$. The GSTT1 effects on FVC and $\mathrm{FEF}_{25-75}$ were comparable in size and direction, but did not reach statistical significance. Men carrying the double homozygous gene deletions of GSTT1 and GSTM1 had on average a $-8.3 \mathrm{ml} / \mathrm{yr}$ greater annual decline in FEV1 than men with at least one copy of both, the GSTT1 and the GSTM1 gene ( $\mathrm{P}$ for trend $<0.001$ ); the according excess change was $-6.5 \mathrm{ml} / \mathrm{yr}(\mathrm{P}=0.045)$ for $\mathrm{FVC}$ and $-7.8 \mathrm{ml} / \mathrm{yr}$ $(\mathrm{P}=0.094)$ for $\mathrm{FEF}_{25-75}$. The interactions between gender and GSTT1 deletion alone or in combination with GSTM1 deletion were statistically significant for FEV1, $\mathrm{FEF}_{25-75}$ and FVC (for GSTT1/GSTM1 combination only).

\section{INSERT [Table 3]}

The majority of the reported association results did not withhold the conservative Bonferroni correction; however the GSTT1 genotype alone or in combination with GSTM1 genotype showed a significant association with annual change in FEV1 even after Bonferroni correction. The effect of double homozygous GSTT1 and GSTM1 deletion on lung function decline is graphically presented as predicted mean annual FEV1 decline in different genotype/ gender strata. 
Table 2: Characteristics* of the study population, the SAPALDIA Cohort

\begin{tabular}{|c|c|c|c|}
\hline & All & Women & Men \\
\hline $\mathrm{N}$ & 4686 & $2455 / 52.4 \%$ & $2231 / 47.6 \%$ \\
\hline Age [years] & $40.8( \pm 11.5)$ & $4 I .2( \pm 1 \mathrm{I} .4)$ & $40.4( \pm 11.6)$ \\
\hline $\mathrm{BMI}$ at baseline $[\mathrm{kg} / \mathrm{m} 2]$ & $23.7( \pm 3.6)$ & $22.9( \pm 3.8)$ & $24.5( \pm 3.2)$ \\
\hline BMI at follow-up [kg/m2] & $25.8( \pm 4.4)$ & $25.2( \pm 4.8)$ & $26.5( \pm 3.8)$ \\
\hline \multicolumn{4}{|l|}{ Weight change } \\
\hline during follow-up [kg] & $5.6( \pm 6.2)$ & $5.5( \pm 6.1)$ & $5.7( \pm 6.3)$ \\
\hline \multicolumn{4}{|l|}{ Smoking $\dagger$} \\
\hline Never smokers & $2258 / 48.2$ & $1354 / 55.2$ & $904 / 40.5$ \\
\hline Ever smokers & $2428 / 51.8$ & $1101 / 44.8$ & $1327 / 59.5$ \\
\hline Persistent smokers & $1026 / 21.9$ & $487 / 19.8$ & $539 / 24.2$ \\
\hline Others & $1402 / 29.9$ & $614 / 25.0$ & $788 / 35.3$ \\
\hline Pack-years up to baseline $\ddagger$ & $18.4( \pm 18.4)$ & $14.5( \pm \mid 4.5)$ & $21.8( \pm 20.6)$ \\
\hline Pack-years during follow-up $\ddagger$ & $6.4( \pm 8.5)$ & $5.5( \pm 6.5)$ & $7.1( \pm 9.8)$ \\
\hline \multicolumn{4}{|l|}{ Lung Function } \\
\hline FEVI at baseline [L] & $3.6( \pm 0.8)$ & $3.1( \pm 0.6)$ & $4.1( \pm 0.7)$ \\
\hline FVC at baseline [L] & $4.5( \pm 1.1)$ & $3.8( \pm 0.6)$ & $5.3( \pm 0.8)$ \\
\hline FEF25-75 at baseline [L] & $3.4( \pm 1.2)$ & $3.1( \pm 1.0)$ & $3.8( \pm 1.3)$ \\
\hline Annual change FEVI [ml/yr] & $-35.5( \pm 30.2)$ & $-31.8( \pm 26.2)$ & $-39.6( \pm 33.6)$ \\
\hline Annual change FVC $[\mathrm{ml} / \mathrm{yr}]$ & $-24.2( \pm 41.0)$ & $-20.6( \pm 34.9)$ & $-28.3( \pm 46.5)$ \\
\hline Annual change FEF25-75 [ml/yr] & $-71.3( \pm 65.4)$ & $-68.6( \pm 59.4)$ & $-74.1( \pm 71.2)$ \\
\hline FEVI \% pred. at baseline $\S$ & $100.2( \pm 13.3)$ & $100.8( \pm 13.4)$ & $99.4( \pm 13.2)$ \\
\hline FEVI \% pred. at follow-up $\S$ & $97.0( \pm 14.4)$ & $98.6( \pm 14.1)$ & $95.4( \pm 14.6)$ \\
\hline FEVI/FVC at baseline [\%] & $79.2( \pm 7.6)$ & $80.4( \pm 7.4)$ & $78.0( \pm 7.7)$ \\
\hline FEVI/FVC at follow-up [\%] & $74.8( \pm 7.5)$ & $75.5( \pm 7.1)$ & $74.0( \pm 7.8)$ \\
\hline FEVI/FVC at follow-up $<70 \%$ & $1030 / 22.0$ & $473 / 19.3$ & $557 / 25.0$ \\
\hline Positive BHR at baseline [\%] & $612 / 16.1$ & $394 / 20.3$ & $218 / 11.7$ \\
\hline \multicolumn{4}{|l|}{ Genotypes } \\
\hline GSTMI deletion & $2477 / 52.9$ & $1306 / 53.2$ & $11171 / 52.5$ \\
\hline GSTTI deletion & $844 / 18.0$ & $466 / 19.0$ & $378 / 17.0$ \\
\hline \multicolumn{4}{|l|}{ GSTPI lle I05Val } \\
\hline Ile/lle & $2219 / 47.4$ & $1162 / 47.3$ & $1057 / 47.4$ \\
\hline Ile/Val & $2025 / 43.2$ & $1068 / 43.5$ & $957 / 42.9$ \\
\hline $\mathrm{Val} / \mathrm{Val}$ & $442 / 9.4$ & $225 / 9.2$ & $217 / 9.7$ \\
\hline
\end{tabular}

* expressed as mean $( \pm \mathrm{SD})$ for quantitative variables and absolute numbers/percentages for categorical variable.

† "Never" smokers reported non-smoking at both surveys. "Persistent" smokers reported current smoking at both surveys. "Others" comprised participants reporting at both surveys former smoking $(n=944)$, quitting smoking during follow-up $(n=387)$, starting smoking during follow-up $(n$ $=38$ ), non-smoking at baseline and former smoking at follow-up $(n=29)$ and former smoking at baseline and current smoking at follow-up $(n=4)$. $\ddagger$ mean of pack-years among ever smoking subjects. Ever-smokers encompass both, persistent smokers and others.

$\S \mathrm{FEVI} \%$ predicted calculations based on predicted values from SAPALDIA specific prediction equations [55, 56].

\section{INSERT [Figure 1]}

\section{Effect modification by smoking}

An important determinant of premature lung function decline is active smoking. In our study population, persistent male smokers exhibited on average an $-6.6 \mathrm{ml} / \mathrm{yr}$ greater annual FEV1 change than never smoking men; the average change in FEV1 was $-42.8 \mathrm{ml} / \mathrm{yr}( \pm 35.6)$ in male persistent smokers and $-36.2 \mathrm{ml} / \mathrm{yr}( \pm 33.2)$ in male never smokers. In persistent smokers each pack-year smoked during follow-up was associated with an excess average annual FEV1 change of $-0.8 \mathrm{ml} / \mathrm{yr}$. We assessed the impact of genetic GST deficiency on lung function decline sepa- rately for never smokers and persistent smokers; associations observed in ever-smokers were similar to those reported here for persistent smokers (data not shown). Irrespective of gender or smoking status no independent effects of GSTM1 or GSTP1 Ile105Val genotype on accelerated decline of FEV1, FVC or $\mathrm{FEF}_{25-75}$ were observed. Male persistent smokers with GSTT1 null genotype exhibited on average an excess annual decline in FEV1 of -8.0 $\mathrm{ml} / \mathrm{yr}(\mathrm{P}=0.013)$ when compared to persistent smokers with GSTT1 non-null genotype. The according GSTT1 effect in male never smokers was $-5.6 \mathrm{ml} / \mathrm{yr}(\mathrm{P}=0.025)$. The difference in GSTT1 effect between persistent and never smokers was not statistically significant ( $P$ for inter- 
Table 3: Adjusted* associations of GST genotypest with excess annual decline in FEVI, FVC and FEF $25-75$ stratified by sex, the SAPALDIA Cohort.

\begin{tabular}{|c|c|c|c|c|c|c|c|c|c|c|c|}
\hline \multicolumn{12}{|c|}{ Difference in mean annual change in lung function $(\mathrm{ml} / \mathrm{yr}) \ddagger$} \\
\hline \multicolumn{3}{|c|}{ FEVI (ml/yr) } & \multirow[b]{2}{*}{ p-value $\S$} & \multicolumn{3}{|c|}{ FVC (ml/yr) } & \multirow[b]{2}{*}{ p-value $\S$} & \multicolumn{3}{|c|}{$\mathbf{F E F}_{25-75}(\mathbf{m l} / \mathbf{y r})$} & \multirow[b]{2}{*}{ p-value $\S$} \\
\hline $\mathbf{n}$ & Coeff. & $95 \% \mathrm{Cl}$ & & $\mathbf{n}$ & Coeff. & $95 \% \mathrm{Cl}$ & & $\mathbf{n}$ & Coeff. & $95 \% \mathrm{Cl}$ & \\
\hline \multicolumn{12}{|c|}{ MEN } \\
\hline 1853 & --- & & --- & 1806 & --- & & --- & 1787 & --- & & --- \\
\hline 378 & -5.3 & $-8.4,-2.1$ & $0.0019^{* *}$ & 371 & -5.2 & $-7.4,-1.3$ & 0.17 & 366 & -5.0 & $-11.7,1.8$ & 0.15 \\
\hline 1060 & --- & & --- & 1040 & -- & & -- & 1030 & --- & & --- \\
\hline$|17|$ & -2.1 & $-4.5,0.3$ & 0.081 & 1137 & -0.8 & $-4.0,2.5$ & 0.65 & 1123 & -4.1 & $-9.2,0.9$ & 0.11 \\
\hline 1057 & --- & & --- & 1037 & --- & & --- & 1025 & --- & & --- \\
\hline 957 & 0.09 & $-2.4,2.6$ & 0.94 & 929 & -0.1 & $-3.5,3.3$ & 0.95 & 919 & -2.7 & $-8.0,2.6$ & 0.32 \\
\hline 217 & -2.5 & $-6.6,1.7$ & 0.25 & 211 & -3.2 & $-9.0,2.5$ & 0.27 & 209 & -7.3 & $-16.1,1.6$ & 0.11 \\
\hline 885 & --- & & -- & 866 & -- & & -- & 860 & -- & & -- \\
\hline 1143 & -1.8 & $-4.3,0.7$ & --- & 1114 & 0.9 & $-2.5,4.4$ & --- & 1097 & -5.1 & $-10.5,0.2$ & --- \\
\hline 203 & -8.3 & $-12.6,-3.9$ & $<0.001 \prod^{* *}$ & 197 & -6.5 & $-12.5,-0.5$ & $0.045 \pi$ & 196 & -7.8 & $-17.0,1.5$ & 0.094 \\
\hline & & & 0.30 & & & & $0.042 \pi$ & & & & 0.55 \\
\hline \multicolumn{12}{|c|}{ WOMEN } \\
\hline 1989 & --- & & --- & 1953 & --- & & --- & 1920 & --- & & --- \\
\hline 466 & -0.3 & $-2.5,1.8$ & 0.76 & 462 & -1.6 & $-4.5,1.3$ & 0.28 & 455 & 3.4 & $-1.5,8.3$ & 0.18 \\
\hline 1149 & -- & & --- & $113 \mid$ & -- & & -- & 1115 & --- & & --- \\
\hline 1306 & 0.5 & $-1.2,2.2$ & 0.54 & 1284 & 1.1 & $-1.2,3.4$ & 0.36 & 1260 & -0.8 & $-4.7,3.1$ & 0.69 \\
\hline 1162 & --- & & --- & 1142 & --- & & --- & 1126 & --- & & -- \\
\hline 1068 & -0.6 & $-2.4,1.2$ & 0.51 & 1050 & 0.6 & $-1.8,3.0$ & 0.64 & 1030 & -3.0 & $-7.0,1.1$ & 0.15 \\
\hline 225 & -0.2 & $-3.3,2.9$ & 0.90 & 223 & 1.5 & $-2.6,5.6$ & 0.48 & 219 & 0.5 & $-6.5,7.5$ & 0.88 \\
\hline 931 & --- & & --- & 915 & --- & & --- & 902 & --- & & --- \\
\hline 1276 & -0.9 & $-2.7,1.0$ & --- & 1254 & -1.1 & $-3.5,1.4$ & --- & $|23|$ & -0.6 & $-4.8,3.5$ & --- \\
\hline 248 & 1.6 & $-1.5,4.6$ & 0.24 & 246 & 1.3 & $-2.7,5.4$ & 0.42 & 242 & 3.2 & $-3.6,10.0$ & 0.53 \\
\hline & & & $0.026 \pi$ & & & & $0.025 \pi$ & & & & 0.66 \\
\hline \multicolumn{12}{|c|}{ Sex* Genotype Interaction $\dagger \dagger$} \\
\hline & & & $0.010 \pi$ & & & & 0.56 & & & & $0.043 \pi$ \\
\hline & & & $0.028 \pi$ & & & & 0.23 & & & & 0.19 \\
\hline & & & 0.50 & & & & 0.39 & & & & 0.40 \\
\hline & & & $<0.001 \pi$ & & & & $0.015 \pi$ & & & & $0.08 \pi$ \\
\hline
\end{tabular}

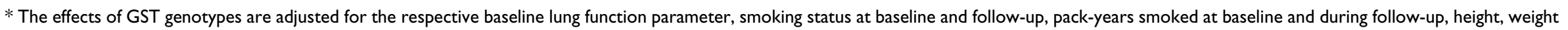
change between surveys, study area, gas and dust exposure at baseline and education level.

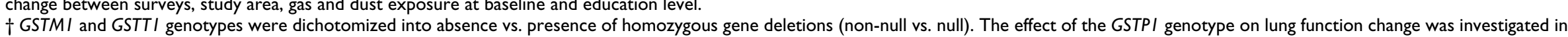

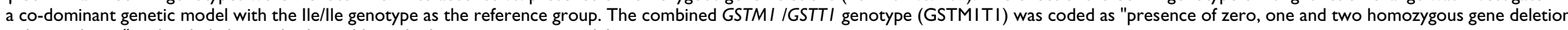
polymorphisms" and included as ordinal variable in the linear regression model.

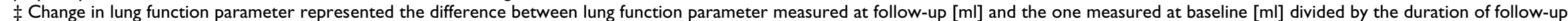

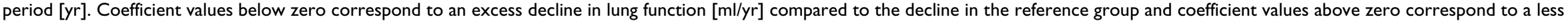
steep decline in lung function compared of the reference group.

§Uncorrected $\mathrm{P}$-values for differences between categories. Bonferroni corrected significance level for multiple comparisons: $\mathrm{P}<0.0017$.

TStatisically significant (uncorrected P-value $>0.05$ ). ** Statistically significant after Bonferoni-correction $(P$-value $>0.0017)$

t† Interaction between genotype and gender was assessed by including interaction terms in the model. 


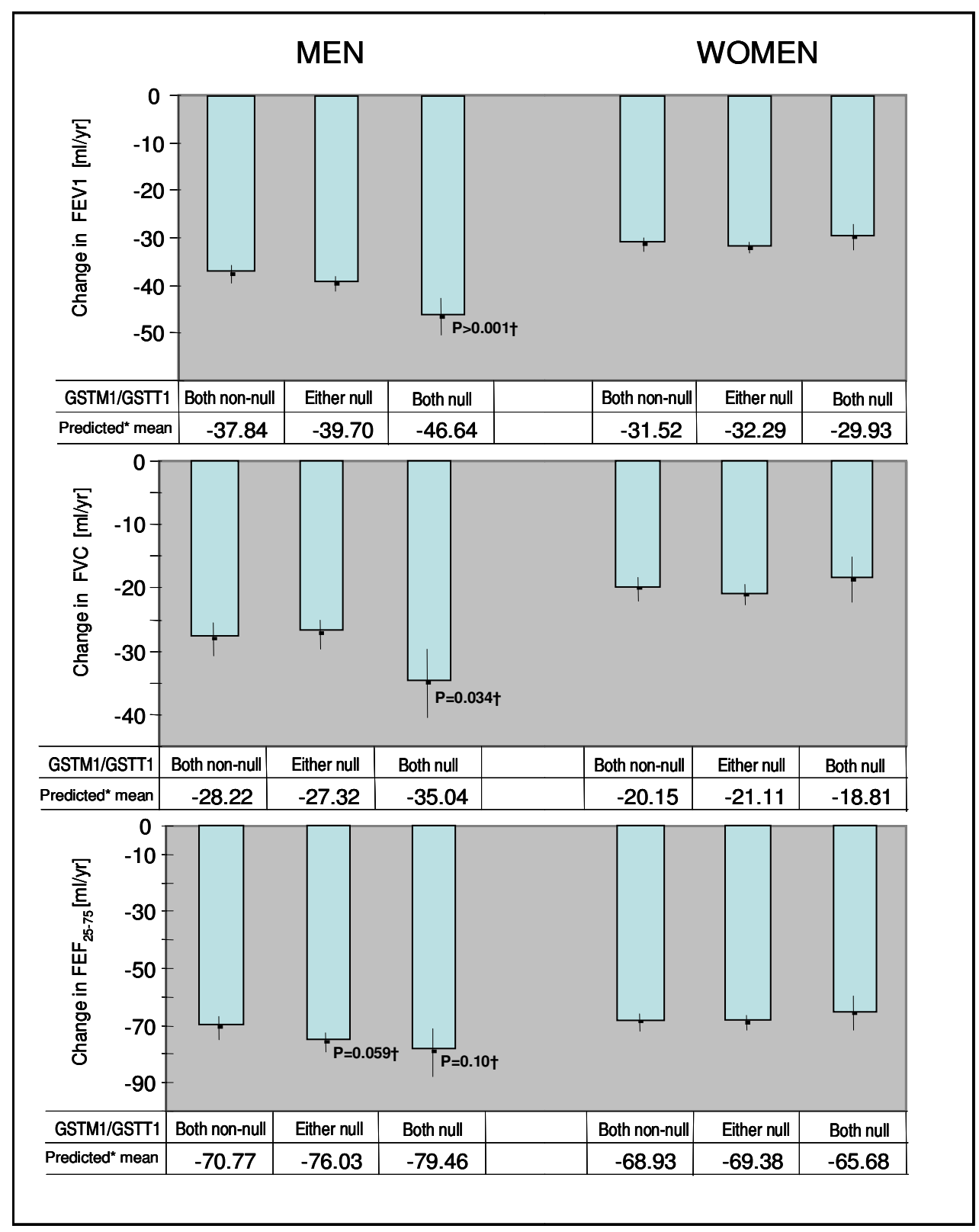

Figure I

Predicted* mean annual change in lung function parameter by the combined GSTTI and GSTMI gene deletion genotype and sex, the SAPALDIA cohort.

* adjusted for baseline FEVI, FVC and $\mathrm{FEF}_{25-75}$, respectively, as well as for smoking status at baseline and follow-up, pack-years smoked at baseline and during follow-up, height, weight change between surveys, study area, gas and dust exposure at baseline and education level.

† P-values for difference with reference group GSTMITI both non-null. 
action>0.10). The GSTT1 effect in persistent smokers was modified by packyears smoked to baseline ( $\mathrm{P}$ for interaction<0.001) and during follow-up $(\mathrm{P}$ for interaction $=$ 0.029). Similar trends for the GSTT1 effect on FEV1 decline in smoking strata, though lacking statistical significance, were observed for FVC and less clearly for $\mathrm{FEF}_{25-75}$. The GSTT1 genotype alone or in combination with GSTM1 genotype was not associated with excess lung function change in women, irrespective of smoking status. There was a suggestion that heterozygosity for the GSTP1 Ile105Val SNP was associated with slower decline in FVC in persistent smokers $(P=0.030)$, but no according heterozygous effects on FEV1 or $\mathrm{FEF}_{25-75}$ were observed.

\section{INSERT [Table 4]}

\section{Sensitivity analysis: modification of the GST effects by BHR}

The GST genotypes have previously been associated with asthma and BHR [28]. Restriction of the analysis to subjects without a report of asthma (data not shown) and without the presence of BHR at either baseline or followup (Table 5) revealed comparable associations in size between GST genotypes and lung function change as reported for the whole study population (Table 3 ), irrespective of gender and lung function parameter. Thus the observed GST/lung function decline associations are not merely due to an effect of GST on asthma or BHR.

BHR was previously shown to be predictive of COPD [29]. Results of the investigation of the GST effects on decline in lung function among BHR positive subjects (Table 5) suggested that the respective impact of GSTT1 and GSTM1 gene deletion might be modified by BHR. The interaction between GST genotypes and BHR did not reach statistical significance, though. In male BHR positive subjects, GSTM1 rather then GSTT1 deficiency was associated with accelerated decline in FEV1 $(-8.2 \mathrm{ml} / \mathrm{yr}, \mathrm{P}=0.017)$ and $\mathrm{FEF}_{25-75}(-12.4 \mathrm{ml} / \mathrm{yr}, \mathrm{P}=0.051)$. Again, the lung function decline was strongest for the combined GSTM1/GSTT1 genotypes, consistent with a gene dose-response. For both, FEV1 and $\mathrm{FEF}_{25-75}$ effect estimates for GSTM1T1 both null were stronger than those observed among male BHR negative subjects. No association of GST genotype with FVC was observed in male BHR positive subjects. In BHR positive women again no statistically significant GST genotype/lung function associations were observed.

\section{INSERT [Table 5]}

\section{Sensitivity analysis: GST effect in age restricted subpopulation}

Both, lung function growth and decline are age-dependent processes. The SAPALDIA cohort also includes young adults (age at baseline 18 to 60 years). To confirm that the observed associations between GST genotype and lung function change are due to an impact of these genotypes on age-related decline, we restricted analysis to subjects older than 30 years, an age at which lung growth has ceased and age-related lung function decline started [30] (data not presented). In men we observed associations of GSTT1 alone or in combination with GSTM1 with change in FEV1 and FVC that were similar in trend to the ones observed in the entire study sample (for GSTT1 and FEV1: $-5.8 \mathrm{ml} / \mathrm{yr}(\mathrm{P}=0.001)$; for GSTM1 and GSTT1 both null and FEV1: $-7.4 \mathrm{ml} / \mathrm{yr}(\mathrm{P}=0.009))$. The association with change in FVC was more pronounced (for GSTT1: $-4.4 \mathrm{ml} /$ yr $(\mathrm{P}=0.08)$; for GSTM1 and GSTT1 both null: $-9.5 \mathrm{ml} / \mathrm{yr}$ $(P=0.005))$. In contrast, the non-significant association observed for GSTT1 genotype and change in $\mathrm{FEF}_{25-75}$ was no longer present in men aged 30 years or older (for GSTT1: $-0.4 \mathrm{ml} / \mathrm{yr}(\mathrm{P}=0.89)$; for GSTM1 and GSTT1 both null: $-1.9 \mathrm{ml} / \mathrm{yr}(P=0.72))$. Instead, the association between GSTM1 null genotype and excess annual change in $\mathrm{FEF}_{25-75}$ became statistically significant (for GSTM1: $7.6 \mathrm{ml} / \mathrm{yr}(\mathrm{P}=0.024))$. In women over age 30 at baseline, we did not observe any GST genotype/lung function decline association.

\section{Discussion}

Our results suggest that genetic GSTT1 deficiency alone or in combination with GSTM1 deficiency is independently associated with an accelerated age-related decline of lung function in men, but not women, irrespective of smoking status. The impact size of the GSTT1 genotype was comparable to the difference in FEV1 decline that we observed between male persistent smokers and never smokers.

This is the first study reporting an association between GST genotypes and lung function in the general adult population. Genetically determined GST deficiency has previously been associated with deficits in lung function growth and respiratory symptoms in healthy and asthmatic children exposed to oxidative inhalants such as high ambient ozone concentrations and passive smoke, respectively $[20,31]$. While GSTs are well known for their role in the metabolism of exogenous toxic substrates including tobacco derived substances, they also exhibit peroxidase activity and thus might play an important role in oxidative stress defense [15]. The fundamental relevance of the oxidative stress pathway to respiratory health and disease is evidenced by the fact that dietary and circulating antioxidants have been suggested by a number of epidemiological studies to protect the lung from accelerated pulmonary function decline and other respiratory diseases [32-34]. The current observation that the GST genotype effects were even present in never smokers living in study areas with moderate concentrations of ambient ozone and other air pollutants is in line with this notion and with experimental data suggesting that various air pollutants as 


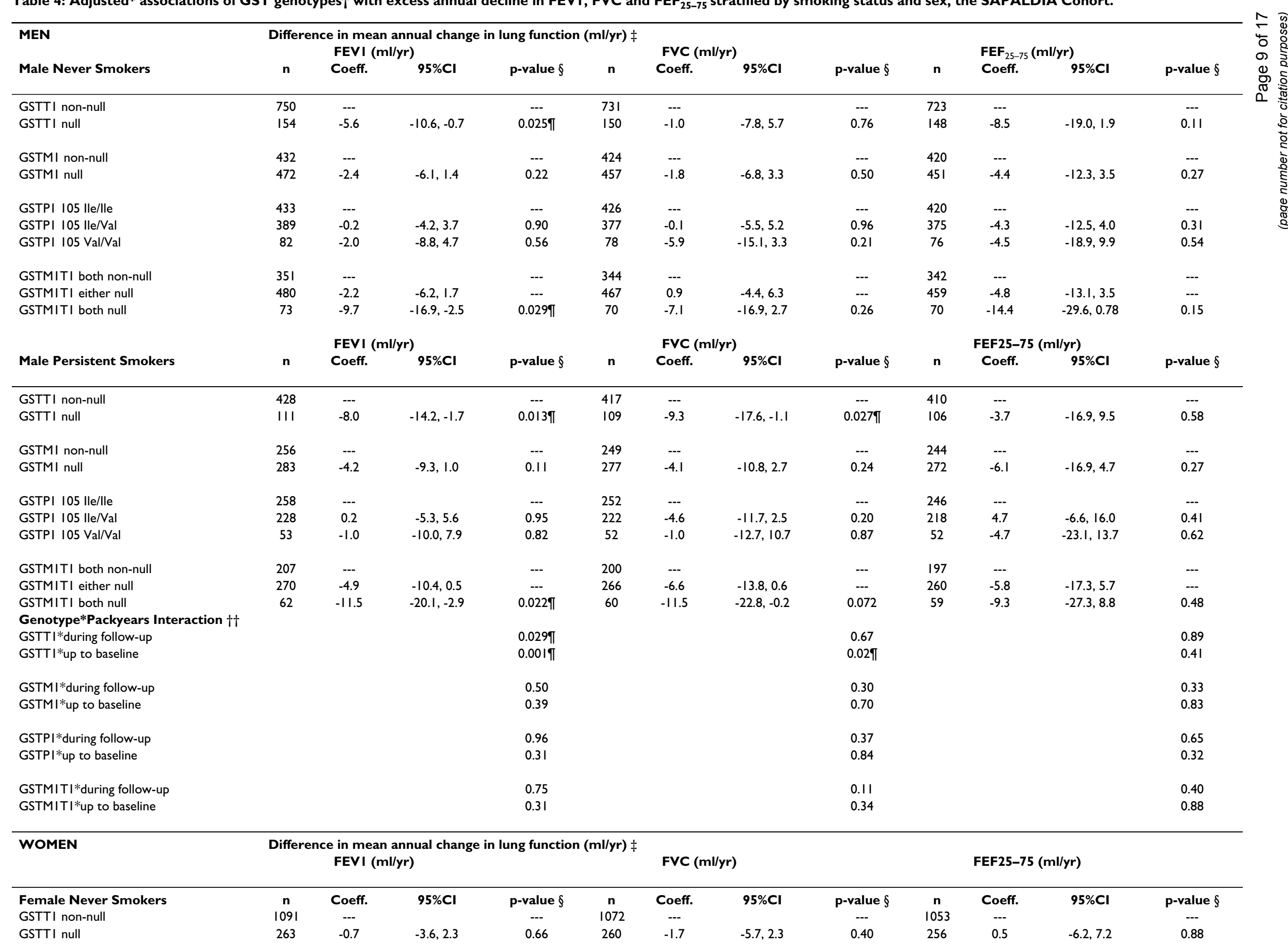


Table 4: Adjusted* associations of GST genotypes $\nmid$ with excess annual decline in FEVI, FVC and FEF ${ }_{25-75}$ stratified by smoking status and sex, the SAPALDIA Cohort. (Continued)

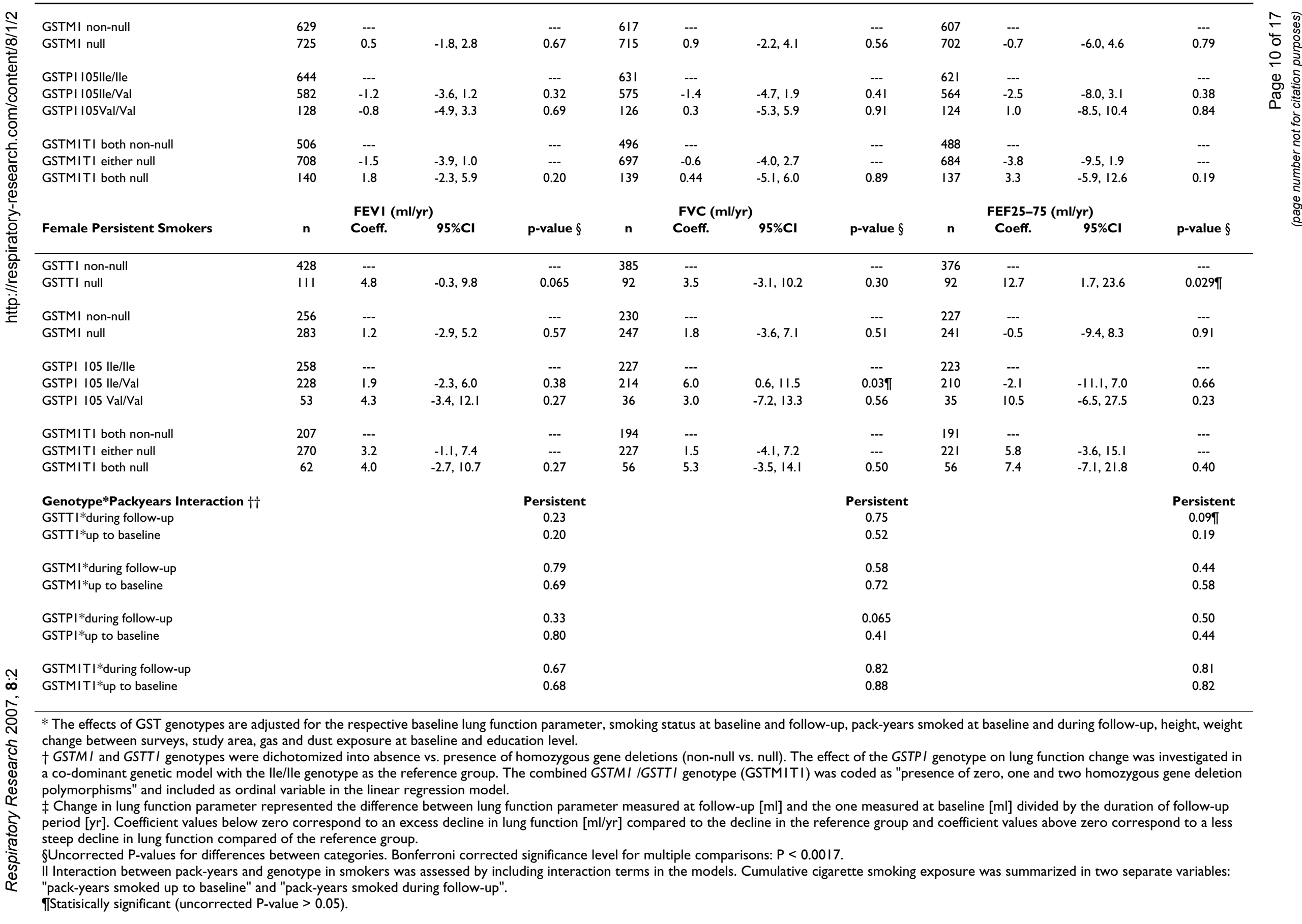


Table 5: Adjusted* associations of GST genotypes $\nmid$ with excess annual decline in FEVI, FVC and FEF 25-75 in men and women, stratified by absence or presence of BHR at baseline or follow-up, the SAPALDIA Cohort.

\begin{tabular}{|c|c|c|c|c|c|c|c|c|c|c|c|c|}
\hline \multirow{3}{*}{$\begin{array}{l}\text { BHR } \\
\text { negative }\end{array}$} & \multicolumn{12}{|c|}{ Difference in mean annual change in lung function $(\mathrm{ml} / \mathrm{yr}) \ddagger$} \\
\hline & \multicolumn{3}{|c|}{ FEVI (ml/yr) } & \multicolumn{4}{|c|}{ FVC $(\mathrm{ml} / \mathrm{yr})$} & \multicolumn{4}{|c|}{ FEF25-75 (ml/yr) } & \multirow[b]{2}{*}{ p-value $\S$} \\
\hline & $\mathbf{n}$ & Coeff. & $95 \% \mathrm{Cl}$ & p-value $\S$ & $\mathbf{n}$ & Coeff. & $95 \% \mathrm{Cl}$ & p-value $\S$ & $\mathbf{n}$ & Coeff. & $95 \% \mathrm{Cl}$ & \\
\hline \multicolumn{13}{|l|}{ MEN } \\
\hline GSTTI non-null & 965 & --- & & --- & 948 & --- & & --- & 941 & --- & & --- \\
\hline GSTTI null & 209 & -4.4 & $-8.3,-0.5$ & $0.027 \pi$ & 208 & -3.8 & $-9.0,1.3$ & 0.14 & 207 & -4.2 & $-13.2,4.8$ & 0.36 \\
\hline GSTMI non-null & 560 & --- & & --- & 550 & --- & & --- & 546 & --- & & --- \\
\hline GSTMI null & 614 & -0.8 & $-3.8,2.2$ & 0.58 & 606 & 0.2 & $-3.7,4.2$ & 0.91 & 602 & -3.4 & $-10.4,3.5$ & 0.33 \\
\hline GSTPI $105 \mathrm{lle} / \mathrm{lle}$ & 557 & --- & & --- & 547 & --- & & --- & 542 & --- & & --- \\
\hline GSTPI 105 Ile/Val & 511 & 0.9 & $-4.1,2.2$ & 0.56 & 505 & -0.7 & $-4.9,3.4$ & 0.95 & 503 & -4.3 & $-11.6,2.9$ & 0.24 \\
\hline GSTPI $105 \mathrm{Val} / \mathrm{Val}$ & 106 & -0.6 & $-6.0,4.9$ & 0.84 & 104 & -0.7 & $-7.9,6.6$ & 0.86 & 103 & -3.7 & $-16.3,9.0$ & 0.57 \\
\hline GSTMITI both non-null & 460 & --- & & --- & 450 & --- & & --- & 447 & --- & & --- \\
\hline GSTMITI either null & 605 & -0.5 & $-3.7,2.7$ & --- & 598 & 0.7 & $-3.5,4.9$ & --- & 593 & -3.2 & $-10.5,4.1$ & --- \\
\hline \multirow[t]{3}{*}{ GSTMITI both null } & 109 & -6.4 & $-11.8,-1.0$ & 0.062 & 108 & -5.1 & $-12.3,2.1$ & 0.27 & 108 & -8.0 & $-20.5,4.5$ & 0.41 \\
\hline & \multicolumn{4}{|c|}{ FEVI (ml/yr) } & \multicolumn{3}{|c|}{ FVC (ml/yr) } & \multicolumn{5}{|c|}{ FEF25-75 ( $\mathrm{ml} / \mathrm{yr})$} \\
\hline & $\mathbf{n}$ & Coeff. & $95 \% \mathrm{Cl}$ & p-value $\S$ & $\mathbf{n}$ & Coeff. & $95 \% \mathrm{Cl}$ & p-value $\S$ & $\mathbf{n}$ & Coeff. & $95 \% \mathrm{Cl}$ & p-value $\S$ \\
\hline \multicolumn{13}{|l|}{ WOMEN } \\
\hline GSTTI non-null & 812 & --- & & --- & 808 & --- & & --- & 803 & --- & & --- \\
\hline GSTTI null & 181 & 1.2 & $-1.8,4.1$ & 0.43 & 181 & 0.3 & $-3.9,4.5$ & 0.88 & 180 & 5.4 & $-2.0,12.9$ & 0.15 \\
\hline GSTMI non-null & 459 & --- & & --- & 458 & --- & & --- & 456 & --- & & --- \\
\hline GSTMI null & 534 & 0.7 & $-1.6,3.0$ & 0.55 & 531 & 0.2 & $-3.0,3.5$ & 0.88 & 527 & 2.1 & $-3.7,7.8$ & 0.48 \\
\hline GSTPI I05 Ile/lle & 472 & --- & & --- & 470 & --- & & --- & 469 & --- & & --- \\
\hline GSTPI $105 \mathrm{lle} / \mathrm{Val}$ & 430 & -0.6 & $-2.4,1.2$ & 0.51 & 428 & 0.5 & $-2.9,3.9$ & 0.76 & 425 & -5.6 & $-11.6,0.5$ & 0.072 \\
\hline GSTPI I05 Val/Val & 91 & -0.2 & $-3.3,2.9$ & 0.90 & 91 & 4.3 & $-1.6,10.2$ & 0.15 & 89 & -3.6 & $-14.1,6.9$ & 0.50 \\
\hline GSTMITI both non-null & 373 & --- & & --- & 372 & --- & & --- & 370 & --- & & --- \\
\hline GSTMITI either null & 525 & -1.5 & $-3.9,0.9$ & --- & 522 & -1.1 & $-4.6,2.3$ & --- & 519 & 4.4 & $-1.7,10.6$ & --- \\
\hline GSTMITI both null & 95 & 0.1 & $-4.1,4.3$ & 0.24 & 95 & 2.3 & $-3.6,8.1$ & 0.46 & 94 & 5.5 & $-5.0,15.9$ & 0.31 \\
\hline
\end{tabular}

\begin{tabular}{|c|c|c|c|c|c|c|c|c|c|c|c|c|}
\hline \multirow{3}{*}{$\begin{array}{l}\text { BHR } \\
\text { positive }\end{array}$} & \multicolumn{12}{|c|}{ Difference in mean annual change in lung function $(\mathrm{ml} / \mathrm{yr}) \ddagger$} \\
\hline & \multicolumn{3}{|c|}{ FEVI (ml/yr) } & \multicolumn{4}{|c|}{ FVC $(\mathrm{ml} / \mathrm{yr})$} & \multicolumn{5}{|c|}{ FEF25-75 (ml/yr) } \\
\hline & $\mathbf{n}$ & Coeff. & $95 \% \mathrm{Cl}$ & p-value $\S$ & $\mathbf{n}$ & Coeff. & $95 \% \mathrm{Cl}$ & p-value $\S$ & $\mathbf{n}$ & Coeff. & $95 \% \mathrm{Cl}$ & p-value $\S$ \\
\hline \multicolumn{13}{|l|}{ MEN } \\
\hline GSTTI non-null & 276 & --- & & --- & 267 & --- & & --- & 265 & --- & & --- \\
\hline GSTTI null & 51 & -5.5 & $-14.7,3.8$ & 0.24 & 50 & -5.5 & $-17.3,6.3$ & 0.36 & 50 & -7.0 & $\begin{array}{c}-24.2 \\
10.2\end{array}$ & 0.42 \\
\hline GSTMI non-null & 165 & --- & & -- & 161 & --- & & --- & 161 & --- & & --- \\
\hline GSTMI null & 162 & -8.2 & $-14.9,-1.5$ & $0.017 \pi$ & 156 & -2.8 & $-11.4,5.8$ & 0.53 & 154 & -12.4 & $\begin{array}{c}-24.9 \\
0.08\end{array}$ & 0.051 \\
\hline GSTPI I05 lle/lle & 142 & --- & & --- & 139 & --- & & --- & 137 & --- & & --- \\
\hline GSTPI $105 \mathrm{lle} / \mathrm{Val}$ & 146 & -0.7 & $-8.0,6.6$ & 0.84 & 139 & -6.0 & $-15.3,3.3$ & 0.20 & 139 & 7.8 & $-5.8,21.4$ & 0.26 \\
\hline GSTPI $105 \mathrm{Val} / \mathrm{Val}$ & 39 & 0.07 & $\begin{array}{c}-10.8 \\
10.9\end{array}$ & 0.99 & 39 & -2.8 & $\begin{array}{c}-16.4 \\
10.9\end{array}$ & 0.69 & 39 & -2.9 & $\begin{array}{c}-22.8 \\
17.0\end{array}$ & 0.77 \\
\hline GSTMITI both non-null & 139 & --- & & -- & 136 & --- & & --- & 136 & --- & & --- \\
\hline GSTMITI either null & 163 & -6.1 & $-13.2,1.0$ & --- & 156 & -0.2 & $-9.3,8.8$ & --- & 154 & -11.6 & $-24.8,1.6$ & --- \\
\hline GSTMITI both null & 25 & -17.3 & $-30.6, .4, I$ & $0.024 \pi$ & 25 & -13.4 & $-30.2,3.4$ & 0.27 & 25 & -20.2 & $-44.6,4.3$ & 0.12 \\
\hline
\end{tabular}

Among men:

interaction

Genotype* BHR †† 
Table 5: Adjusted* associations of GST genotypes† with excess annual decline in FEVI, FVC and FEF $25-75$ in men and women, stratified by absence or presence of BHR at baseline or follow-up, the SAPALDIA Cohort. (Continued)

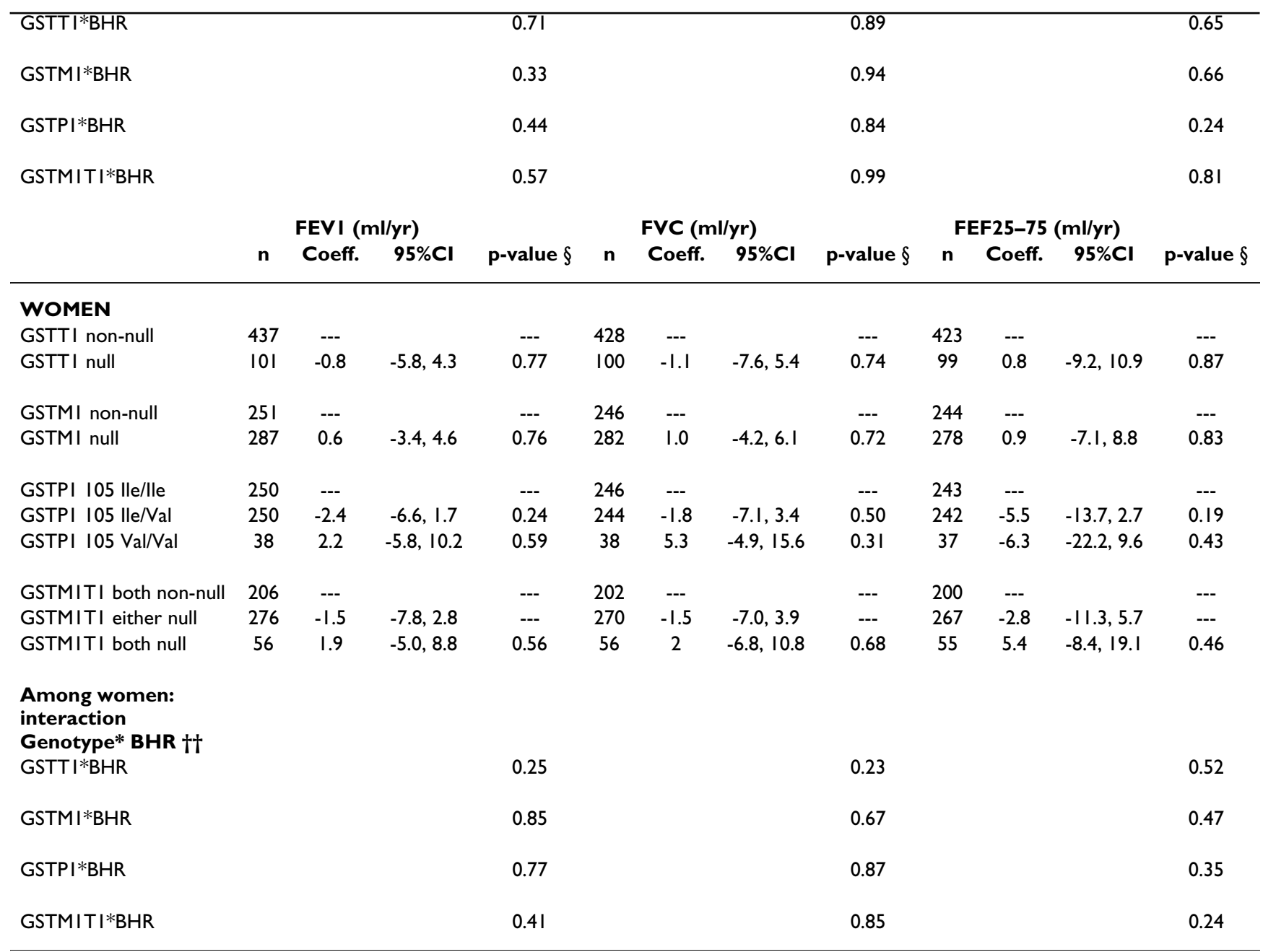

* The effects of GST genotypes are adjusted for the respective baseline lung function parameter, smoking status at baseline and follow-up, packyears smoked at baseline and during follow-up, height, weight change between surveys, study area, gas and dust exposure at baseline and education level.

† GSTMI and GSTTI genotypes were dichotomized into absence vs. presence of homozygous gene deletions (non-null vs. null). The effect of the GSTPI genotype on lung function change was investigated in a co-dominant genetic model with the lle/lle genotype as the reference group. The combined GSTMI /GSTTI genotype (GSTMITI) was coded as "presence of zero, one and two homozygous gene deletion polymorphisms" and included as ordinal variable in the linear regression model.

$\ddagger$ Change in lung function parameter represented the difference between lung function parameter measured at follow-up [ml] and the one measured at baseline [ml] divided by the duration of follow-up period [yr]. Coefficient values below zero correspond to an excess decline in lung function [ml/yr] compared to the decline in the reference group and coefficient values above zero correspond to a less steep decline in lung function compared of the reference group.

$\S$ Uncorrected $\mathrm{P}$-values for differences between categories.

TीStatistically significant (uncorrected P-value $>0.05$ ).

$\dagger$ Interaction between genotype and BHR was assessed by including interaction terms in the model. 
well as chronic inflammatory processes can cause oxidative damage to the lung tissue at low levels [35].

The GSTT1 effect was most consistent for FEV1 and overall comparable in direction for $\mathrm{FVC}$ and $\mathrm{FEF}_{25-75}$ in our study. Yet our results suggest that the respective impacts of GST genotypes on the different lung function parameters may depend on the smoking status, BHR and age. The strength of the GSTT1 association with FVC and $\mathrm{FEF}_{25-75}$ differed between never smokers and persistent smokers. The effect on change in $\mathrm{FEF}_{25-75}$ was not observed in persistent smokers as also reflected by the lack of interaction of smoking history (pack-years) with GSTT1 genotype, suggesting that the GSTT1 affects predominately large airway caliber in smokers. In addition no statistically significant GSTT1 effect on any lung function parameter was observed in subjects with bronchial hyperresponsiveness. Accelerated decline in FEV1 has been well characterized to correlate with development of COPD [36], but measures of small airways function such as changes in $\mathrm{FEF}_{25-75}$ have also been reported to be of relevance in COPD [37]. Air pollutant exposure to ozone [38] and NO2 [39] has often been associated with a greater decline in $\mathrm{FEF}_{25-75}$ than in FEV1. Differences in age, as well as differences in genotypes investigated between our participants and previous study populations may explain in part the inconsistency in the GST effects on various lung function parameters. Alterations in $\mathrm{FEF}_{25-75}$ and $\mathrm{FEF}_{25-75} / \mathrm{FVC}$ have been interpreted as indicators of airway-parenchymal dysanaptic lung growth. These parameters may be of greater relevance as an outcome for GST and oxidant effects during childhood. Ongoing research into genetic determinants of various lung function parameters may provide further insight into the biology of different lung function parameters [40].

A novel finding of our population-based study is the pronounced gender difference in the association between GST genotypes and age-related change in lung function. Though the biological basis of these observed gender differences is unknown, gender differences in lung function and respiratory diseases have consistently been observed throughout life. They can be attributed in part to sex-specific immunological and hormonal patterns associated with lung function [41]. In addition, men and women seem to differ in susceptibility to exogenous exposures. On one hand comparative studies suggest that women recover better than men from the adverse effects of tobacco smoke [42-44]. On the other hand there is evidence that women had greater respiratory deficits per pack-year smoked [45] as well as higher DNA adducts levels when adjusted for cigarette dose [46]. Several other lines of evidence indicate in contrast that women might be more resistant to oxidative stress than men. In smokers, air flow obstruction was reported to be more strongly associated with the presence of high-grade preinvasive epithelial lesion in men than in women [47]. Women compared to men were found to exhibit increased systemic antioxidant capacities such as higher glutathione blood levels [48], increased glutathione peroxidase activity [49] and less oxidant-damaged DNA at advanced age $[50,51]$. In addition, women often report increased antioxidant intake when compared to men, which may make them less receptive for an effect of low penetrance gene variants [34]. Finally, recently reported evidence suggests that the estrogen receptor is involved in the up-regulation of oxidative stress defensive genes including GSTP1 [52] supporting the notion that sex-specific mechanisms in the defense response to oxidative stress exist. If confirmed by additional studies, our results which point to a sex-specific GST impact on lung function might be indicative of a broad biological basis for gender difference in susceptibility to airborne toxicants.

We observed in the male SAPALDIA population differences in the relative impact of specific GST polymorphisms on lung function. In fact, results from previous studies suggest that the respective relevance of GST genes on respiratory health may depend on age, health and exposure status of the study population $[16,18,19,53,54]$. The GSTT1 gene deletion polymorphism has previously been identified as an important determinant of agerelated lung function change $[19,53]$. In the Lung Health Study (LHS) the rate of lung function decline was accelerated in GSTT1 deficient smokers with mild COPD $[19,53]$. No gender difference was observed, but women were underrepresented in the LHS. The GSTT1 effect was stronger in mild as opposed to heavy smokers, whereas in our study the GSTT1 effect was more pronounced in smokers and with increasing pack-years. This discrepancy to the LHS results might be attributable to the comparatively better respiratory health state of the SAPALADIA participants (FEV1 \% pred. [55,56] at follow-up: 97\%) and to their more moderate smoking habits. The relative impact of specific GST genotypes on lung function in children may be different from that in adults. Gilliland et al. [20] reported lower lung function growth in children with GSTP1 105Val and GSTM1 null genotypes, but not with GSTT1 null genotype. In agreement with our results, no independent GSTM1 effect on pulmonary function was observed in healthy, non-smoking freshmen students, irrespective of their antioxidant intake [34]. Exclusion of younger age groups in our study population did not modify the reported associations, demonstrating that the findings on association between GST genotypes and lung function change were mostly due to the genotype impact on age related lung function decline rather than on lung function growth. As suggested by our sensitivity analysis the relative impact of GSTT1 or GSTM1 gene deletion may also depend on the presence or absence of BHR. There is 
evidence that BHR responsive airways are more vulnerable to oxidative particles and to airway inflammation in general [57]. This altered physiology of the BHR positive lung tissue might provide a pathophysiologic basis for the respective impact of GSTM1 deficiency reported here.

Results are most inconsistent with regard to the GSTP1 Ile105Val genotype. The GSTP1 105Val allele was found to be protective against asthma and BHR [54]. In the LHS study GSTP1 105Val/Val genotype was associated with lower lung function at baseline as well as with more rapid lung function decline in smokers with high baseline lung function values [19]. Yet the combination of GSTM1 and GSTT1 gene deletion and GSTP1 105Ile/Ile was defined as risk genotype in the follow-up study of the LHS [53]. In other studies, the GSTP1 105Ile/Ile genotype was inconsistently associated with COPD $[13,54,58]$. In vitro assays further underline the complexity of the functional impact of the GSTP1 Ile105Val polymorphism, since the relative activity of the variants is substrate dependent [59]. GSTP1, the most abundantly expressed member of the GST gene family in the lung [60], may have a complex impact on respiratory disease. GSTP1 appears to act not only as a detoxifying and antioxidative enzyme, but also as direct inhibitor of the C-Jun $\mathrm{N}$ terminal kinase [61]. Accordingly, low GSTP1 expression or activity has been reported to promote apoptosis in lung epithelium [54,62]. Future studies investigating more comprehensively genetic variation and haplotypes of the GSTP1 gene should improve our understanding of the role of GSTP1 at various developmental and phenotypic levels of respiratory health.

The strength of the SAPALDIA cohort is its prospective design, its large sample size as well as the detailed characterization of study participants. However, several limitations of the study deserve to be discussed. First, the study cohort was evaluated at two single time points eleven years apart and the range of factors influencing lung function decline were assessed through personal interviews depending on reporting/recalling bias of the study participants. Also there is the concern for selection bias for participation at follow-up. Comparison of baseline characteristics of SAPALDIA participants included in this investigation with SAPALDIA cohort participants not included in this analysis due to missing covariate information suggested that the population sample investigated here represents a younger, and less actively smoking and healthier sample. GST genotypes were not associated with age or smoking behavior among subjects included in this study. Since it is not likely that GST genotypes influenced study participation, non-participation at baseline, loss to follow-up and exclusion of participants due to lacking covariate information is unlikely to invalidate the results presented. Second, a hypothetical limitation of our association study may be potential population stratification since the Swiss population consists of multiple language groups. Deviation of HWE of the GSTP1 Ile105Val genotype was not observed within the three language groups presented in our study (French, German and Italian); the genotype distribution was comparable in the three language groups. The prevalence of gene deletion genotypes of GSTM1 and GSTT1 and were not statistically significantly different by language region or nationality. Neither language group nor Swiss nationality did modify the observed associations between GST deficient genotypes and lung function decline. Given the low power of HWE [63], genotype data from additional unlinked genetic markers should ideally be used for testing population admixture [64]. However limited funding prohibited this control of population stratification in our study. Nevertheless we do not expect population stratification in this Swiss cohort to invalidate the observed associations since genetic homogeneity of Caucasian Western-Central European populations [65] has been repeatedly described. A further limitation of the study is the fact that the genetic analysis chosen does not permit to disentangle heterozygotes from homozygotes wild type GSTT1 or GSTM1 genotypes. It is conceivable that even stronger associations with lung function could have been observed in a contrast of subjects without any deletion allele versus no GSTT1 and GSTM1 gene. Finally sample size was limited for the assessment of GST genotype effects among BHR positive subjects.

In conclusion our results suggest that common genetic polymorphisms can influence the rate of lung function decline in the general population. A large proportion of the Caucasian population carry one or both GST gene deletions ( $20 \%$ of GSTT1 gene deletion, $50 \%$ the GSTM1 gene deletion and 10\% of GSTT1/GSTM1 gene deletion carriers). The high prevalence and the strong effect size, which is comparable to the effect of smoking, underscore the public health relevance of our results. Additional studies need to confirm and identify the biological mechanisms underlying the newly observed gender difference in GST genotype effects on age-related lung function decline.
Abbreviations
BHR - Bronchial hyperresponsiveness
BMI - Body Mass Index
COPD - chronic obstructive pulmonary disease
DNA - desoxyribonucleic acid
EDTA - ethylenediaminetetraacetic acid
FEV1 - forced expiratory volume in one second 
FVC - forced vital capacity

GST - Glutathione S-transferase

HWE - Hardy-Weinberg equilibrium

Ile - isoleucine

LHS - Lung Health Study

PCR - polymerase chain reaction

SAPALDIA - Study on Air Pollution And Lung Disease In Adults

Val - valine

\section{Competing interests}

The author(s) declare that they have no competing interests.

\section{Authors' contributions}

NMPH conceived the specific research question and designed the SAPALDIA biological sample collection. MI and NMPH established the SAPALDIA DNA bank. OS, MI performed genotype analysis. GM, WB gave major infrastructure support and technical advice for DNA bank establishment and large scale genotyping. NMPH, OB, EWR obtained funding. NMPH, CS, OB, EWR are involved in SAPALDIA Cohort Study and UAL was the coprincipal investigator of the SAPALDIA Cohort Study. SHD, CS, MI, OS did the health data management. MI, NMPH, SHD performed data analysis. SHD, CS gave statistical support. All authors contributed to the interpretation of the data and gave critical review during manuscript process. MI and NP drafted the manuscript and all authors read and approved the final manuscript.

\section{Acknowledgements}

The authors thank the participants of the SAPALDIA cohort for participation and interest in this research. We also thank Esther Glaus for her technical thoroughness in extracting the DNA.

The SAPALDIA cohort study directorate is composed of principal investigator T. Rochat, the former co-principal investigator P. Leuenberger, $U$. Ackermann-Liebrich, J.C. Barthélémy, S.Liu, C. Schindler and NM. ProbstHensch and of the numerous contributors of the SAPALDIA cohort study are not listed as authors: the local centre teams and coordinators of both SAPALDIA surveys and the members of the scientific SAPALDIA team: J.C. Barthélémy, R. Bettschart, A. Bircher, K. Blaser, G. Bolognini, M. Brutsche, L. Burdet, M. Frey, J.M. Gaspoz, M. Gerbase, D. Gold, W. Karrer, R. Keller, B. Knöpfli, N. Künzli, A. Morabia, U. Neu, L. Nicod, A.P. Perruchoud, M. Pons, T. Rochat, P. Schmid-Grendelmeyer, J. Schwartz, F. Schwarz, P. Straehl, J.M. Tschopp, A. von Eckardstein, J.P. Zellweger, E. Zemp Stutz, L. Bayer-Oglesby, D. Felber Dietrich, D. Keidel, B. Kuna-Dibbert, P. StädeleKessler.
Funding Resources:

The research has been supported by the Swiss National Science Foundation (grant $N^{\circ}$ 33-47CO-108796/I, N NF32-65896.0I, NF32-58996.99, NF3254996.98 Prosper: NM. Probst), Freiwillige Akademische Gesellschaft Basel and Lung Ligue Zürich.

\section{References}

I. Lopez AD, Murray CC: The global burden of disease, 19902020. Nat Med 1998, 4:124I-I243.

2. Calverley PM, Walker P: Chronic obstructive pulmonary disease. Lancet 2003, 362:1053-1061.

3. Kunzli N, Ackermann-Liebrich U, Brandli O, Tschopp JM, Schindler C, Leuenberger P: Clinically "small" effects of air pollution on FVC have a large public health impact. Swiss Study on Air Pollution and Lung Disease in Adults (SAPALDIA) - team. Eur Respir J 2000, 15:131-136.

4. Matheson MC, Benke G, Raven J, Sim MR, Kromhout H, Vermeulen $\mathrm{R}$, Johns DP, Walters EH, Abramson MJ: Biological dust exposure in the workplace is a risk factor for chronic obstructive pulmonary disease. Thorax 2005, 60:645-65I.

5. Schikowski T, Sugiri D, Ranft U, Gehring U, Heinrich J, Wichmann HE, Kramer U: Long-term air pollution exposure and living close to busy roads are associated with COPD in women. Respir Res 2005, 6: 152.

6. Eisner MD, Balmes J, Yelin EH, Katz PP, Hammond SK, Benowitz N, Blanc PD: Directly measured secondhand smoke exposure and COPD health outcomes. BMC Pulm Med 2006, 6:12.

7. DeMeo DL, Silverman EK: Alphal-antitrypsin deficiency. 2: genetic aspects of alpha(I)-antitrypsin deficiency: phenotypes and genetic modifiers of emphysema risk. Thorax 2004, 59:259-264.

8. Demeo DL, Mariani TJ, Lange C, Srisuma S, Litonjua AA, Celedon JC, Lake SL, Reilly JJ, Chapman HA, Mecham BH, Haley KJ, Sylvia JS, Sparrow D, Spira AE, Beane J, Pinto-Plata V, Speizer FE, Shapiro SD, Weiss ST, Silverman EK: The SERPINE2 Gene Is Associated with Chronic Obstructive Pulmonary Disease. Am J Hum Genet 2006, 78:253-264.

9. Kelleher CM, Silverman EK, Broekelmann T, Litonjua AA, Hernandez M, Sylvia JS, Stoler J, Reilly JJ, Chapman HA, Speizer FE, Weiss ST, Mecham RP, Raby BA: A functional mutation in the terminal exon of elastin in severe, early-onset chronic obstructive pulmonary disease. Am J Respir Cell Mol Biol 2005, 33:355-362.

10. Guenegou A, Leynaert B, Benessiano J, Pin I, Demoly P, Neukirch F, Boczkowski J, Aubier M: Association of lung function decline with the heme oxygenase-I gene promoter microsatellite polymorphism in a general population sample. Results from the European Community Respiratory Health Survey (ECRHS), France. J Med Genet 2006, 43:e43.

II. Hersh CP, Demeo DL, Lazarus R, Celedon JC, Raby BA, Benditt JO, Criner G, Make B, Martinez FJ, Scanlon PD, Sciurba FC, Utz JP, Reilly Jj, Silverman EK: Genetic association analysis of functional impairment in chronic obstructive pulmonary disease. $\mathrm{Am} J$ Respir Crit Care Med 2006, 173:977-984.

12. Hoffjan S, Stemmler S, Parwez Q, Petrasch-Parwez E, Arinir U, Rohde G, Reinitz-Rademacher K, Schultze-Werninghaus G, Bufe A, Epplen JT: Evaluation of the toll-like receptor 6 Ser249Pro polymorphism in patients with asthma, atopic dermatitis and chronic obstructive pulmonary disease. BMC Med Genet 2005, 6:34.

13. Cheng SL, Yu CJ, Chen CJ, Yang PC: Genetic polymorphism of epoxide hydrolase and glutathione S-transferase in COPD. Eur Respir J 2004, 23:818-824.

14. Hayes JD, Pulford $D$ J: The glutathione S-transferase supergene family: regulation of GST and the contribution of the isoenzymes to cancer chemoprotection and drug resistance. Crit Rev Biochem Mol Biol 1995, 30:445-600.

15. Hayes JD, Strange RC: Glutathione S-transferase polymorphisms and their biological consequences. Pharmacology 2000, 6I:154-166

16. Romieu I, Sienra-Monge J], Ramirez-Aguilar M, Moreno-Macias H, Reyes-Ruiz NI, Estela del Rio-Navarro B, Hernandez-Avila M, London SJ: Genetic polymorphism of GSTMI and antioxidant supplementation influence lung function in relation to ozone exposure in asthmatic children in Mexico City. Thorax 2004, 59:8-10. 
17. Aynacioglu AS, Nacak M, Filiz A, Ekinci E, Roots I: Protective role of glutathione S-transferase PI (GSTPI) Vall 05Val genotype in patients with bronchial asthma. Br J Clin Pharmacol 2004, 57:213-217.

18. Flamant C, Henrion-Caude A, Boelle PY, Bremont F, Brouard J, Delaisi B, Duhamel JF, Marguet C, Roussey M, Miesch MC, Boule M, Strange RC, Clement A: Glutathione-S-transferase MI, M3, P I and TI polymorphisms and severity of lung disease in children with cystic fibrosis. Pharmacogenetics 2004, I 4:295-30 I.

19. He JQ, Ruan J, Connett JE, Anthonisen NR, Pare PD, Sandford AJ: Antioxidant gene polymorphisms and susceptibility to a rapid decline in lung function in smokers. Am J Respir Crit Care Med 2002, 166:323-328.

20. Gilliland FD, Gauderman WJ, Vora H, Rappaport E, Dubeau L: Effects of glutathione-S-transferase MI, TI, and PI on childhood lung function growth. Am J Respir Crit Care Med 2002, 166:710-716.

21. Ackermann-Liebrich U, Kuna-Dibbert B, Probst-Hensch NM, Schindler C, Felber Dietrich D, Zemp Stutz E, Bayer-Oglesby L, Baum F, Brändli O, Brutsche M, Downs SH, Keidel D, Gerbase MW, Imboden M, Keller R, Knöpfli B, Künzli N, Nicod L, Pons M, Staedele $P$, Tschopp JM, Zellweger JP, Leuenberger P, team SAPALDIA: Followup of the Swiss Cohort Study on Air Pollution and Lung Diseases in Adults (SAPALDIA 2) 1991-2003: methods and characterization of participants. Soz Praventiv Med 2005, 50:245-263.

22. Martin BW, Ackermann-Liebrich U, Leuenberger P, Kunzli N, Stutz EZ, Keller R, Zellweger JP, Wuthrich B, Monn C, Blaser K, Bolognin G, Bongard JP, Brandli O, Braun P, Defila C, Domenighetti G, Grize L, Karrer W, Keller-Wossidlo H, Medici TC, Peeters A, Perruchoud AP, Schindler C, Schoeni MH, Villiger B, et al.: SAPALDIA: methods and participation in the cross-sectional part of the Swiss Study on Air Pollution and Lung Diseases in Adults. Soz Praventivmed 1997, 42:67-84.

23. Kunzli N, Kuna-Dibbert B, Keidel D, Keller R, Brändli O, Schindler C, Schweinzer KM, Leuenberger P, Ackermann-Liebrich U, team SAPALDIA: Longitudinal validity of spirometers - a challenge in lung function follow-up studies. Swiss Medical Weekly 2005, 135(33-34):503-508.

24. Standardization of Spirometry, 1994 Update. American Thoracic Society. Am J Respir Crit Care Med 1995, 152: I I07-I I 36.

25. Schneider S, Roessli D, Excoffier L: Arlequin ver 2000: A software for population genetics data analysis. Genetics \& Biometry Laboratory, University of Geneva, Switzerland 2000.

26. Fleiss JL: Analysis of data from multiclinic trials. Control Clin Trials 1986, 7:267-275.

27. Kelada SN, Kardia SL, Walker AH, Wein AJ, Malkowicz SB, Rebbeck TR: The glutathione S-transferase-mu and -theta genotypes in the etiology of prostate cancer: genotype-environment interactions with smoking. Cancer Epidemiol Biomarkers Prev 2000 9:1329-1334.

28. Fryer AA, Bianco A, Hepple M, Jones PW, Strange RC, Spiteri MA: Polymorphism at the glutathione S-transferase GSTP locus. A new marker for bronchial hyperresponsiveness and asthma. Am J Respir Crit Care Med 2000, 16 1: 1437-1442.

29. Brutsche MH, Downs SH, Schindler C, Gerbase MW, Schwartz J, Frey M, Russi EW, Ackermann-Liebrich U, Leuenberger P: Bronchial hyperresponsiveness and the development of asthma and COPD in asymptomatic individuals: SAPALDIA cohort study. Thorax 2006, 61:67I-677.

30. Janssens JP, Pache JC, Nicod LP: Physiological changes in respiratory function associated with ageing. Eur Respir J 1999 13:197-205.

31. Kabesch M, Hoefler C, Carr D, Leupold W, Weiland SK, von Mutius E: Glutathione $S$ transferase deficiency and passive smoking increase childhood asthma. Thorax 2004, 59:569-573.

32. Morabia A, Sorenson A, Kumanyika SK, Abbey H, Cohen BH, Chee E: Vitamin A, cigarette smoking, and airway obstruction. $A m$ Rev Respir Dis 1989, 140:1312-1316.

33. Britton JR, Pavord ID, Richards KA, Knox AJ, Wisniewski AF, Lewis SA, Tattersfield AE, Weiss ST: Dietary antioxidant vitamin intake and lung function in the general population. Am J Respir Crit Care Med 1995, I5 I:1383-1387.

34. Tujague J, Bastaki M, Holland N, Balmes JR, Tager IB: Antioxidant intake, GSTMI polymorphism and pulmonary function in healthy young adults. Eur Respir J 2006, 27:282-288.
35. Kelly FJ, Dunster C, Mudway I: Air pollution and the elderly: oxidant/antioxidant issues worth consideration. Eur Respir J Suppl 2003, 40:70s-75s.

36. Wise RA: The value of forced expiratory volume in I second decline in the assessment of chronic obstructive pulmonary disease progression. Am J Med 2006, I I 9:4- I I.

37. Niewoehner DE, Kleinerman J, Rice DB: Pathologic changes in the peripheral airways of young cigarette smokers. N Engl J Med 1974, 29 I:755-758.

38. Romieu I, Sienra-Monge JJ, Ramirez-Aguilar M, Tellez-Rojo MM, Moreno-Macias H, Reyes-Ruiz NI, del Rio-Navarro BE, Ruiz-Navarro MX, Hatch G, Slade R, Hernandez-Avila M: Antioxidant supplementation and lung functions among children with asthma exposed to high levels of air pollutants. Am J Respir Crit Care Med 2002, I 66:703-709.

39. Hong YC, Leem JH, Lee KH, Park DH, Jang JY, Kim ST, Ha EH: Exposure to air pollution and pulmonary function in university students. Int Arch Occup Environ Health 2005, 78: I 32-I 38.

40. DeMeo DL, Celedon JC, Lange C, Reilly JJ, Chapman HA, Sylvia JS, Speizer FE, Weiss ST, Silverman EK: Genome-wide linkage of forced mid-expiratory flow in chronic obstructive pulmonary disease. Am J Respir Crit Care Med 2004, I 70: I294-I30I.

4I. Becklake MR, Kauffmann F: Gender differences in airway behaviour over the human life span. Thorax 1999, 54: I I 19- I I38.

42. Griffith KA, Sherrill DL, Siegel EM, Manolio TA, Bonekat HW, Enright PL: Predictors of loss of lung function in the elderly: the Cardiovascular Health Study. Am J Respir Crit Care Med 200I, 163:6I-68.

43. Downs SH, Brandli O, Zellweger JP, Schindler C, Kunzli N, Gerbase MW, Burdet L, Bettschart R, Zemp Stutz E, Frey M, Keller R, Tschopp JM, Leuenberger P, Ackermann-Liebrich U, team SAPALDIA: Heterogeneity in effects from smoking on lung function decline between men and women - SAPALDIA 2 cohort study. Respir Res 2005, 6:45.

44. Connett JE, Murray RP, Buist AS, Wise RA, Bailey WC, Lindgren PG, Owens GR: Changes in smoking status affect women more than men: results of the Lung Health Study. Am J Epidemiol 2003, 157:973-979.

45. Chen Y, Horne SL, Dosman JA: Increased susceptibility to lung dysfunction in female smokers. Am Rev Respir Dis 1991, I 43: 1224- 1230

46. Ryberg D, Hewer A, Phillips DH, Haugen A: Different susceptibility to smoking-induced DNA damage among male and female lung cancer patients. Cancer Res 1994, 54:580I-5803.

47. Lam S, leRiche JC, Zheng Y, Coldman A, MacAulay C, Hawk E, Kelloff G, Gazdar AF: Sex-related differences in bronchial epithelial changes associated with tobacco smoking. I Natl Cancer Inst 1999, 91:691-696.

48. Ilhan N, Kamanli A, Ozmerdivenli R: Variable effects of exercise intensity on reduced glutathione, thiobarbituric acid reactive substance levels, and glucose concentration. Arch Med Res 2004, 35:294-300.

49. Rush JW, Sandiford SD: Plasma glutathione peroxidase in healthy young adults: influence of gender and physical activity. Clin Biochem 2003, 36:345-35I.

50. Fano G, Mecocci P, Vecchiet J, Belia S, Fulle S, Polidori MC, Felzani G, Senin $U$, Vecchiet L, Beal MF: Age and sex influence on oxidative damage and functional status in human skeletal muscle. Muscle Res Cell Motil 200I, 22:345-35I.

5I. Mendoza-Nunez VM, Sanchez-Rodriguez MA, Retana-Ugalde R, Vargas-Guadarrama LA, Altamirano-Lozano MA: Total antioxidant levels, gender, and age as risk factors for DNA damage in lymphocytes of the elderly. Mech Ageing Dev 200I, I 22:835-847.

52. Montano MM, Deng H, Liu M, Sun X, Singal R: Transcriptional regulation by the estrogen receptor of antioxidative stress enzymes and its functional implications. Oncogene 2004, 23:2442-2453.

53. He JQ, Connett JE, Anthonisen NR, Pare PD, Sandford AJ: Glutathione S-transferase variants and their interaction with smoking on lung function. Am J Respir Crit Care Med 2004, I 70:388-394.

54. Ishii T, Matsuse T, Teramoto S, Matsui H, Miyao M, Hosoi T, Takahashi $\mathrm{H}$, Fukuchi $\mathrm{Y}$, Ouchi $\mathrm{Y}$ : Glutathione S-transferase PI (GSTPI) polymorphism in patients with chronic obstructive pulmonary disease. Thorax 1999, 54:693-696.

55. Brandli O, Schindler C, Kunzli N, Keller R, Perruchoud AP: Lung function in healthy never smoking adults: reference values 
and lower limits of normal of a Swiss population. Thorax 1996, 5 I:277-283.

56. Brandli O, Schindler C, Leuenberger PH, Baur X, Degens P, Kunzli N, Keller R, Perruchoud AP: Re-estimated equations for 5 th percentiles of lung function variables. Thorax 2000, 55:173-174.

57. Kohlhaufl M, Brand P, Scheuch G, Meyer TS, Schulz H, Haussinger K, Heyder J: Increased fine particle deposition in women with asymptomatic nonspecific airway hyperresponsiveness. Am J Respir Crit Care Med 1999, I59:902-906.

58. Yim JJ, Park GY, Lee CT, Kim YW, Han SK, Shim YS, Yoo CG: Genetic susceptibility to chronic obstructive pulmonary disease in Koreans: combined analysis of polymorphic genotypes for microsomal epoxide hydrolase and glutathione Stransferase MI and TI. Thorax 2000, 55: I2I-I25.

59. Strange RC, Spiteri MA, Ramachandran S, Fryer AA: Glutathione-Stransferase family of enzymes. Mutat Res 200I, 482:2I-26.

60. Piipari R, Nurminen T, Savela K, Hirvonen A, Mantyla T, Anttila S: Glutathione S-transferases and aromatic DNA adducts in smokers' bronchoalveolar macrophages. Lung Cancer 2003, 39:265-272.

61. Elsby R, Kitteringham NR, Goldring CE, Lovatt CA, Chamberlain M, Henderson CJ, Wolf CR, Park BK: Increased constitutive c-Jun $\mathrm{N}$-terminal kinase signaling in mice lacking glutathione Stransferase Pi. J Biol Chem 2003, 278:22243-22249.

62. Ishii T, Fujishiro M, Masuda M, Nakajima J, Teramoto S, Ouchi Y, Matsuse T: Depletion of glutathione S-transferase $\mathbf{P I}$ induces apoptosis in human lung fibroblasts. Exp Lung Res 2003, 29:523-536.

63. Deng HW, Chen WM, Recker RR: Population admixture: detection by Hardy-Weinberg test and its quantitative effects on linkage-disequilibrium methods for localizing genes underlying complex traits. Genetics 200I, 157:885-897.

64. Pritchard JK, Rosenberg NA: Use of unlinked genetic markers to detect population stratification in association studies. $\mathrm{Am} J$ Hum Genet 1999, 65:220-228.

65. Roewer L, Croucher PJ, Willuweit S, Lu TT, Kayser M, Lessig R, de Knijff $P$, Jobling MA, Tyler-Smith C, Krawczak M: Signature of recent historical events in the European Y-chromosomal STR haplotype distribution. Hum Genet 2005, I I6:279-291.

Publish with Bio Med Central and every scientist can read your work free of charge

"BioMed Central will be the most significant development for disseminating the results of biomedical research in our lifetime. "

Sir Paul Nurse, Cancer Research UK

Your research papers will be:

- available free of charge to the entire biomedical community

- peer reviewed and published immediately upon acceptance

- cited in PubMed and archived on PubMed Central

- yours - you keep the copyright
BioMedcentral 